\title{
Structural characterization of the metamorphic basement from North Dobrogean Promontory (Romania) using geophysical well logging
}

\author{
Constantin-Laurian Ciupercă ${ }^{1, *}$, Bogdan Mihai Niculescu² ${ }^{2}$, and Bogdan Marian Popina ${ }^{3}$ \\ ${ }^{1}$ WEATHERFORD International \\ ${ }^{2}$ University of Bucharest, Faculty of Geology and Geophysics, Department of Geophysics, \\ Bucharest, Romania \\ ${ }^{3}$ OMV PETROM S.A., Bucharest, Romania
}

\begin{abstract}
Metamorphic processes, leading to mineralogical and structural changes of the rocks in response to physical (pressure, temperature) and chemical conditions, can be associated with the development of sinmetamorphic or post-metamorphic fractures. The post-metamorphic ones are directly related to tectonic stress. In addition, tectonic stress may cause the reorientation of minerals on a direction perpendicular to the stress direction, generating foliations (schistosity).

This paper presents a structural analysis of the pre-Alpine metamorphic basement and its relations with the sedimentary cover by using geophysical data recorded in an exploration well located in the North Dobrogean Promontory (Romania). The analysis was based on quad-combo wireline logs, spectral gamma ray, sonic cross-dipole and borehole electrical imaging data. The imaging analysis allowed the identification and characterization of metamorphic foliations, sedimentary bedding, natural fractures and the determination of tectonic stress orientation. A brittleness index was computed by means of elastic parameters derived from density and sonic compressional and shear logs. Also, a fracture intensity characterization by using fracture area per volume of rock was conducted. The integration of geophysical well loging with mud logging and drilling data allowed us to carry out a detailed analysis of the metamorphic basement in the studied area.
\end{abstract}

Keywords: fractures, metamorphic basement, North Dobrogean Promontory, structural characterization, well logging

\section{Introduction}

Metamorphic rocks, resulted from transformation of pre-existing sedimentary or magmatic rocks in response to physical (pressure, temperature) and chemical conditions, may represent reservoirs for hydrocarbons only if they are affected by fracture systems that allow the

\footnotetext{
* Corresponding author: ciupercaconstantin@yahoo.com
} 
hydrocarbons accumulation and migration. Many systems of natural fractures can coexist in the metamorphic reservoirs, having various origins and being formed in different stages of metamorphism or pre-metamorphism. Epimetamorphic rocks may preserve the natural fracture system of the pre-existing rocks. Other type of natural fractures can occur after a metamorphic basement exondation, being subject to subsequent alteration and dissagregation. Generally, the post-metamorphic fractures are directly related to tectonic stress. In addition, tectonic stress may cause the reorientation of minerals in a direction perpendicular to the stress direction, generating foliations (schistosity). The erosion of metamorphic rocks after a basement exondation may lead afterwards to buried relief structures, the sedimentary cover rocks showing differential compaction processes. These can be associated with the creation of domes over the crystalline buried relief.

In this study we present a structural analysis of the pre-Alpine metamorphic basement and its relations with the sedimentary cover, by using geophysical data recorded in an exploration well located in the North Dobrogean Promontory (Romania). The analysis was based on quad-combo openhole wireline logs (total gamma ray, electrical resistivity curves with investigation radii ranging from very shallow to deep, bulk density, thermal neutron porosity), spectral gamma ray, sonic cross-dipole and borehole electrical imaging data (CMI - Compact MicroImager). The borehole electrical image analysis allowed the identification and characterization of metamorphic foliations, sedimentary bedding, natural fractures and the determination of tectonic stress orientation. A brittleness index, as proposed by Rickman et al. [1] and Gray et al. [2], was computed by means of elastic parameters (Young's modulus and Poisson's ratio) derived from density and sonic compressional and shear velocity logs. Also, a fracture intensity characterization by using the fractures area per unit volume of rock, as defined by Dershowitz and Herda [3], was conducted. The integration of geophysical well logging with mud logging and drilling data allowed us to carry out a detailed analysis of the metamorphic basement in the study area.

\section{Geological and tectonic background}

The study area is located within the North Dobrogean Promontory [4, 5], a unit delimited by the regional Peceneaga-Camena Fault and the Central Dobrogea unit towards S and SW, and by the regional Sfântu Gheorghe Fault and the Pre-Dobrogean Depression towards N and NE (Fig. 1 and Fig. 2). The North Dobrogean Promontory represents a prolongation towards NW, underneath Neogene deposits, of the intracratonic North Dobrogean Orogen - a fold-thrust zone of highly deformed Proterozoic, Paleozoic and Mesozoic metamorphic, igneous and sedimentary rocks, which are outcropping E and S of Danube river, in North Dobrogea unit [5]. The North Dobrogean Orogen is the westernmost part of a Cimmerian folded belt extending through southern Crimea to the Asian Cimmerides. It is a nappe complex, consisting of three thrust sheets with northern vergence (Fig. 2): the Niculițel nappe with oceanic affinities, and the Măcin and Tulcea nappes with a Late Proterozoic - Cambrian metamorphic basement [8].

The North Dobrogean Promontory resulted from the sinking of the NW part of North Dobrogean Orogen starting with the Paleogene and consists of a basement (1: the Orliga, Megina and Boclugea meso- and epimetamorphic groups [5, 9, 10, 11], comprising amphibolites, gneisses, micaschists, meta-tuffs, quartzites, phyllites and chlorite-sericite schists; 2: acidic and basic magmatic rocks such as granites, pyroclastites, basalts and gabbros; 3: Paleozoic sedimentary formations, with relatively limited development) and a post-tectonic Neogene sedimentary cover with Badenian (Middle Miocene) - Romanian (Late Pliocene) and Quaternary deposits. 


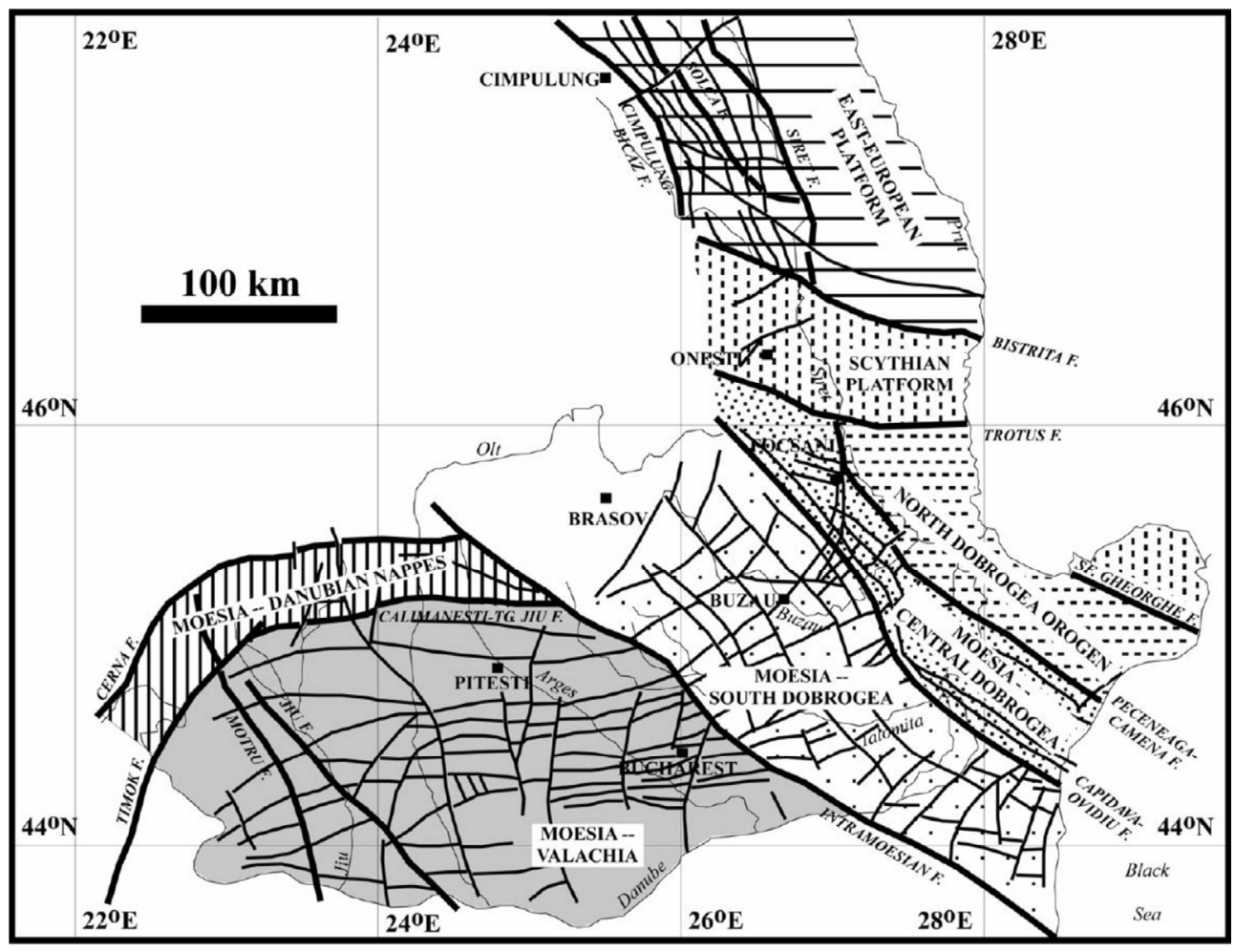

Fig. 1. Simplified tectonic map showing the main units of the South and East Carpathians foreland (East-European Platform, Scythian Platform and Moesian Platform) and the North Dobrogean Orogen and Promontory (based on [6]).



Fig. 2. Location of North Dobrogean Promontory and structure of the North Dobrogean Orogen, as known from outcrops and drill-holes. 1 - Babadag late-Cretaceous cover (post-Peceneaga-Camena fault); 2 - Măcin nappe; 3 - Consul and Niculițel nappes; 4 - Tulcea nappe; 5 -Sfầntu Gheorghe fault (modified from [5] and [7]). 
Regarding the crystalline basement of North Dobrogean Orogen (and North Dobrogean Promontory), some preferential orientations can be observed. For the Orliga medium-grade metamorphic group (considered the oldest metamorphic sequence that outcrops in North Dobrogea area), the identified structures have a E-W orientation, being refolded afterwards on a NW-SE direction. The Megina and the Boclugea medium-grade and, respectively, lowgrade metamorphic groups, are characterized by structures with predominantly NW-SE orientations, subsequently refolded by younger deformation phases [5].

In the area of the analyzed exploration well, the Neogene cover of the North Dobrogean Promontory consists mainly of Pliocene deposits, overlying transgressively in a discordant manner the predominantly crystalline basement. Due to the irregular topography of the basement, the overlaying Pliocene formations frequently appear as domes separated by depressionary areas or by faults. From a lithological standpoint, the Pliocene comprises alternations of fine-grained unconsolidated sandstones, marly sandstones, marls, sandy marls and shales, as revealed by the mud logging records and cores taken from exploration wells drilled in this area.

\section{Geophysical Well Logging Data: Sedimentary Cover - Crystalline Basement Relationship}

The composite plot from Fig. 3 shows the conventional openhole logs and the CMI borehole electrical image - with static normalization of the recorded microconductivity data - for an exploration well drilled in the study area, along with some significant data processing results such as the computed brittleness index $B$ resulting from the elastic properties of the rocks $[1$, 2] and the volumetric fracture intensity $P_{32}$ [3].

The $P_{32}$ parameter, with $\mathrm{m}^{-1}$ units, is defined as the total area of fractures per unit volume, i.e.

$$
P_{32}=A_{f} / V
$$

where $A_{f}$ is the total area of the fractures and $V$ is the volume of the region being measured. $P_{32}$ is direction- and scale-independent and it can be used to classify a given rock mass, being the preferred measure of fracture intensity [12].

The brittleness index $B$, expressed as a percentage, was computed using the expressions

$$
\begin{gathered}
B_{E}=100 \cdot\left(E-E_{\text {min }}\right) /\left(E_{\text {max }}-E_{\text {min }}\right) \\
B_{v}=100 \cdot\left(v-v_{\max }\right) /\left(v_{\min }-v_{\max }\right) \\
B=\left(B_{E}+B_{v}\right) / 2
\end{gathered}
$$

where $E$ is Young's modulus, $v$ is Poisson's ratio, $B_{E}$ is the brittleness estimated from Young's modulus, $B_{v}$ is the brittleness estimated from Poisson's ratio and the subscript min and max denote minimum and maximum values [2].

The boundary between the overlying Pliocene sedimentary rocks and the metamorphic crystalline basement is represented by a nonconformity at approximately $774.6 \mathrm{~m}$ depth (Fig. 3 and Fig. 4). This is clearly marked both on the conventional well logs (increased resistivities and bulk density below the contact, decreased neutron porosity as well as decreased compressional and shear sonic transit times below the contact, indicating compact rocks) and on the color-coded borehole electrical image (rapid change from conductive rocks - dark tones to highly-resistive rocks - light tones). Also, the Pliocene - crystalline basement nonconformity is evidenced by a sharp increase of the brittleness index $B$, whose variations in the basement are generally correlated with the fracture intensity $P_{32}$. Usually, a 
nonconformity suggests a depositional hiatus, in which a long period of erosion occurred prior to deposition of sediments.



Fig. 3. Composite plot showing the basement - sedimentary cover nonconformity. Tracks: 1 auxiliary curves; 2 - CMI statically normalized image; 3 - dip / azimuth tadpoles plot; 4 - total fractures $\left(P_{32}\right) ; 5$ - resistivity curves; 6 - sonic curves; 7 - nuclear curves; 8 - brittleness index $(B)$.

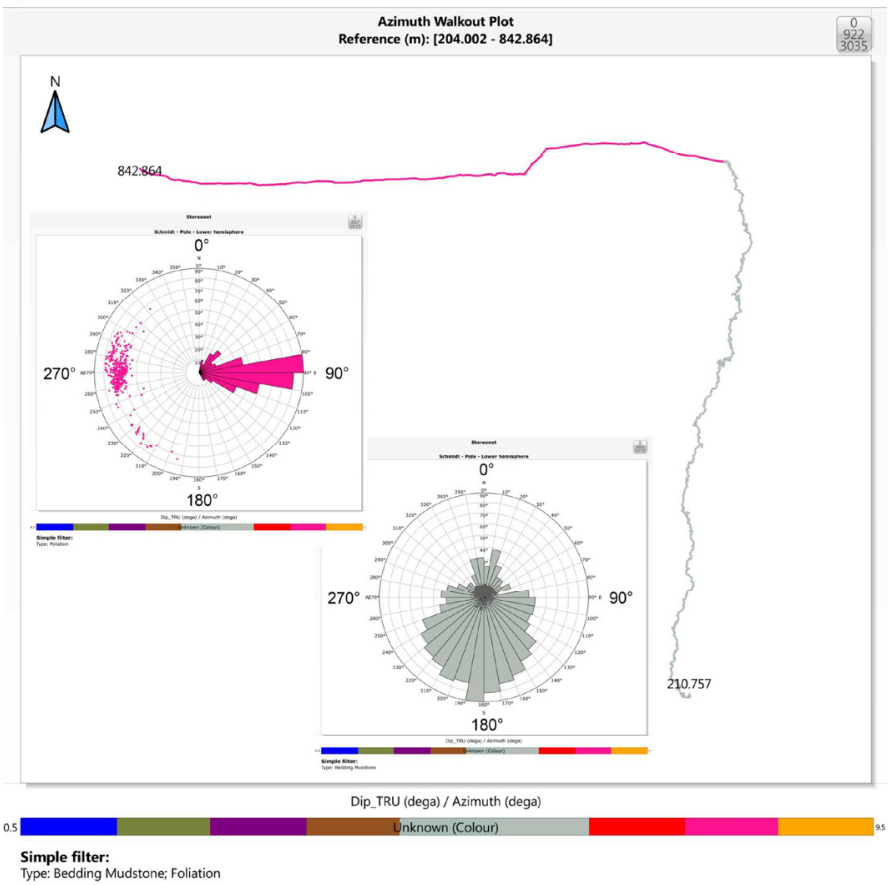

Fig. 4. Azimuth Walkout Plot showing the basement - sedimentary cover nonconformity. 
Just above the crystalline basement rocks, a conglomerate layer of about $4 \mathrm{~m}$ thickness is encountered, as revealed by the borehole microresistivity image texture. This orthoconglomerate formation can be attributed to the dewatering and alteration of the basement rocks. The fracture intensity parameter is increased in the conglomerate area and another 10 $\mathrm{m}$ above. Fracturing processes in this area could be associated with the creation of domes over the crystalline buried relief.

The azimuth vector plot ("walkout plot") in Fig. 4 was constructed by cumulatively stacking unit vectors up through the investigated well. The azimuth of each vector is derived from the dip data ("tadpoles") resulted from the borehole electrical image analysis. The two inset plots / stereonets in Fig. 4 illustrate the distribution of dip angles and dip azimuths (using azimuth frequency plots with $10^{\circ}$ bins) of the planar features identified as shale bedding in the overlying Pliocene deposits and, respectively, interpreted as metamorphic foliations or schistosity in the crystalline basement. The basement is characterized by high-angle dips (frequently $60^{\circ}$ to $80^{\circ}$ ), with predominantly $\mathrm{E}\left(\approx 90^{\circ}\right)$ dip azimuth trend. This eastward dip azimuth implies an approximate N-S strike of the foliations / schistosity. The shale bedding in the sedimentary formations shows very low-angle dips and a general dip azimuth trend towards S to SSW (with a much larger variability of the azimuth values). On the azimuth walkout plot, the Pliocene cover - crystalline basement contact / nonconformity is evidenced by the sudden change in the dip azimuths of the planar features picked on the borehole electrical image.

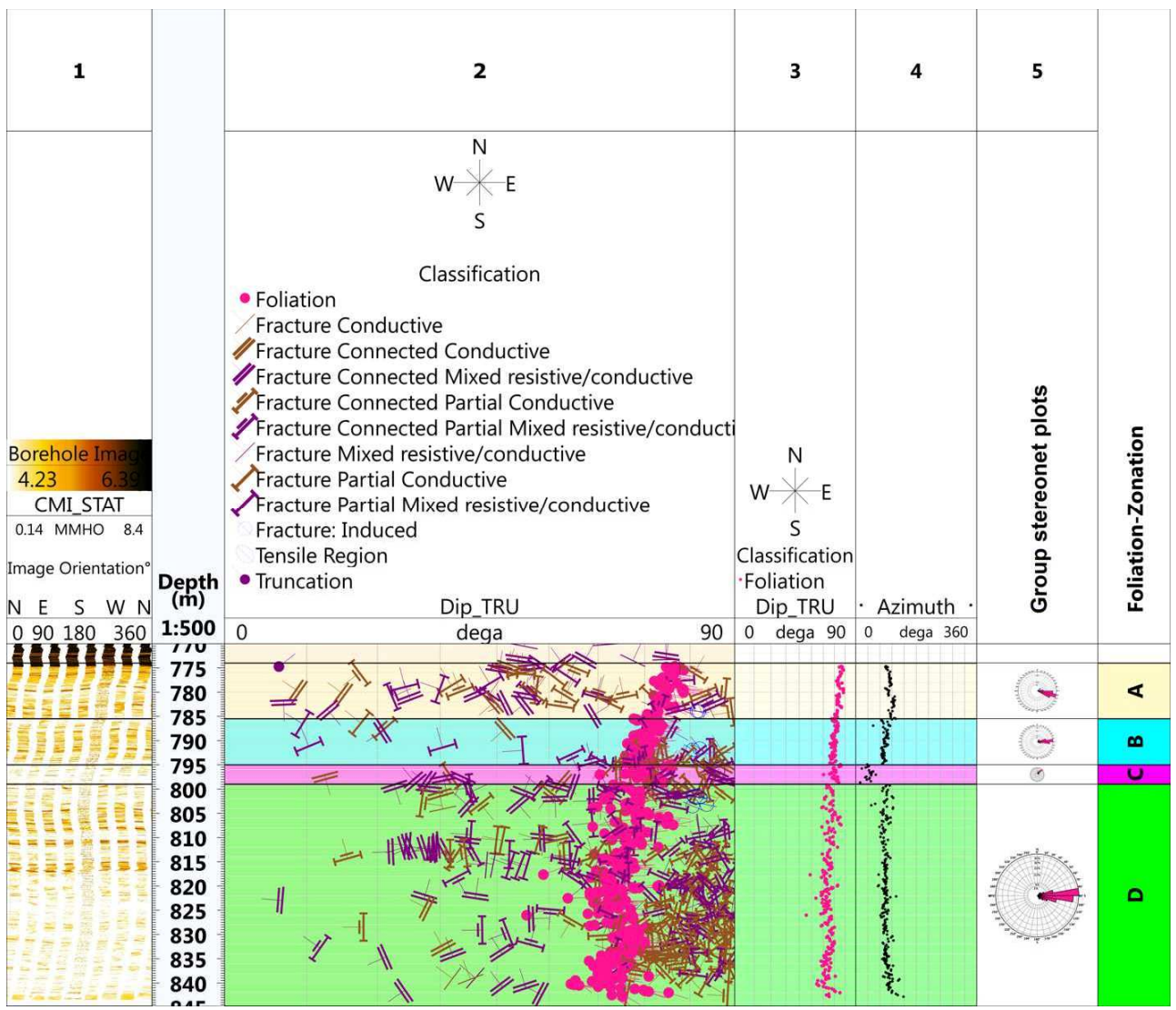

Fig. 5. Borehole electrical image of the crystalline basement, with manually picked dips and azimuths of the various planar features identified on the image. Tracks: 1 - CMI statically normalized image; 2 - dip / azimuth tadpoles plot; 3 - foliation dip; 4 - foliation azimuth; 5 foliation Rose plot. 


\section{Geophysical Well Logging Data: Crystalline Basement Analysis}

Figure 5 presents the crystalline basement interval investigated using borehole electrical imaging (statically normalized image in track 1; lighter tones - low conductivity / high resistivity, darker tones - high conductivity / low resistivity), with the planar features picked from the image (the tadpoles in track 2). These features correspond to metamorphic foliation / schistosity; other picked features correspond to natural or induced fractures within the basement. Tracks 3 and 4 in Fig. 5 show the dips and dip azimuths of the features classified as foliations / schistosity.

A sudden change in azimuth is observed in zone C (795 to $799 \mathrm{~m}$ depth interval), from $90^{\circ}(\mathrm{E})$ to $45^{\circ}(\mathrm{NE})$, with respect to adjacent zones. Possible explanations for such an event may include the occurrence of a local metamorphic differentiation or the presence of another protolith. In Fig. 3, this zone corresponds to the depth interval with the highest values of the fracture intensity $P_{32}$ (track 4) and of the brittleness index $B$ (track 8).

Azimuth vector plots such as the one in Fig. 6 are useful in identifying even subtler azimuth changes throughout the crystalline basement interval, as the one at $785.5 \mathrm{~m}$ depth, used to delineate the upper boundary of zone B / lower boundary of zone A from Fig. 5. Such zonations can be carried out based on the dip, azimuth, fracture intensity and fracture type variability.

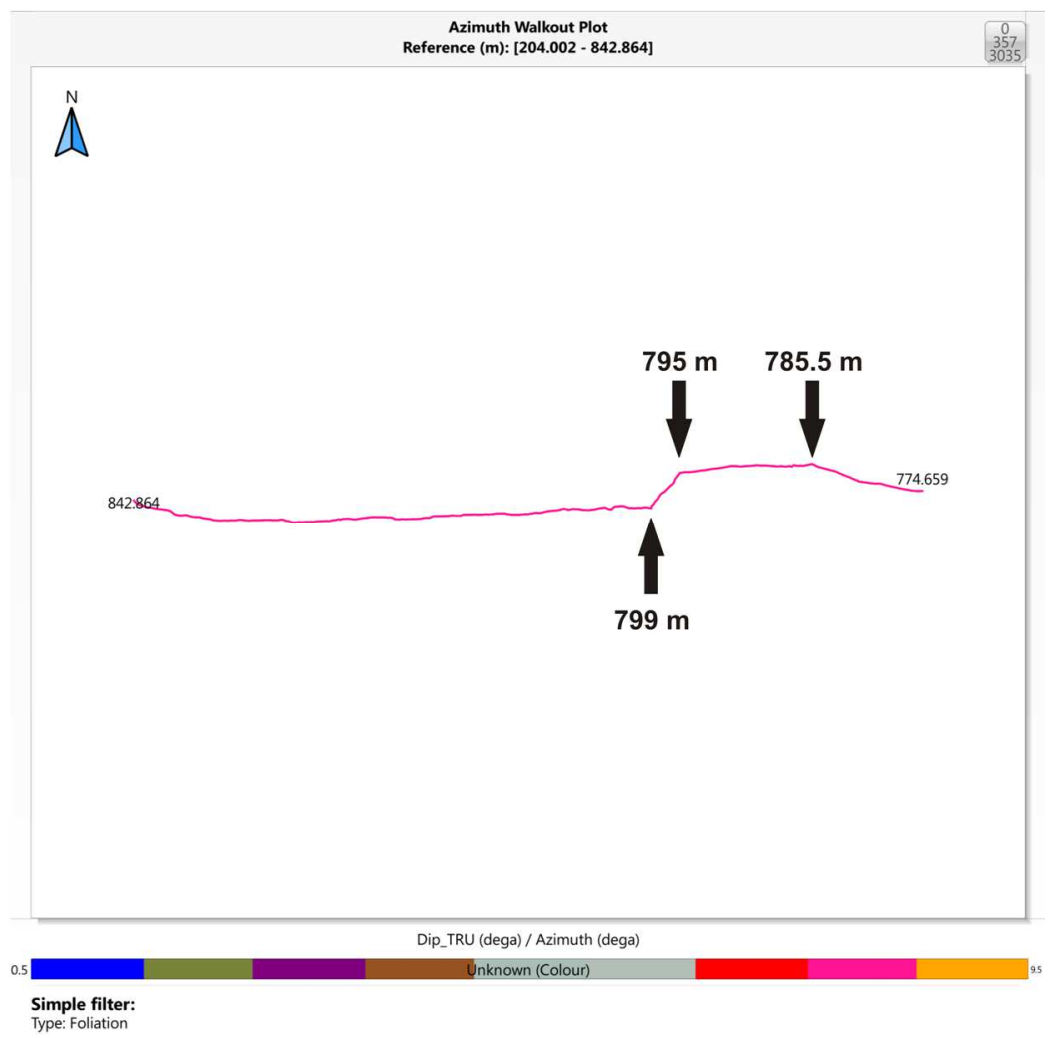

Fig. 6. Azimuth Walkout plot corresponding to the metamorphic foliation or schistosity within the crystalline basement. The marked depths correspond to the boundaries of zones B and C from Fig. 5 . 


\section{Geophysical Well Logging Data: Tectonic Stress Analysis}

Borehole breakouts and drilling-induced fractures are important indicators of horizontal stress orientation. The breakouts are stress-induced enlargements of the wellbore crosssection and occur when the stresses around the borehole exceed those required to cause compressive failure of the borehole wall [13]. The enlargement of the wellbore is caused by the development of shear fractures sub-parallel to the borehole wall, causing pieces of the wall to spall off and creating an ovalized borehole. The long axes of borehole breakouts are oriented approximately perpendicular to the maximum horizontal compressive stress $\left(S_{H}\right)$ orientation, i.e. in the minimum horizontal stress $\left(S_{h}\right)$ direction [14]. Drilling-induced fractures are created when the stresses concentrated around a borehole exceed those required to cause tensile failure of the wellbore wall [15]. They usually appear as narrow sharply defined features that are sub-parallel or slightly inclined to the borehole axis in the vertical wells and are not associated with significant borehole enlargement in the fractures direction. Such fractures develop approximately parallel to the $S_{H}$ orientation [16].

Figure 7 shows the elements which allow the identification of the present-day tectonic stress direction. The oriented 8-arm caliper data of the CMI tool were used to locate borehole ovalizations corresponding to the breakouts orientation $S_{h}$ (track 6 - "Potato Plot" representation). The long axes of the ovalizations are oriented N-S to NNE-SSW, suggesting an approximately E-W or WNW-ESE direction of $S_{H}$. The drilling-induced fractures and the tensile zones were identified too on the electrical image (Fig. 8 - tracks 2, 3, 4) and indicate an approximate WNW-ESE direction of $S_{H}$, confirming the stress direction obtained from borehole breakouts.

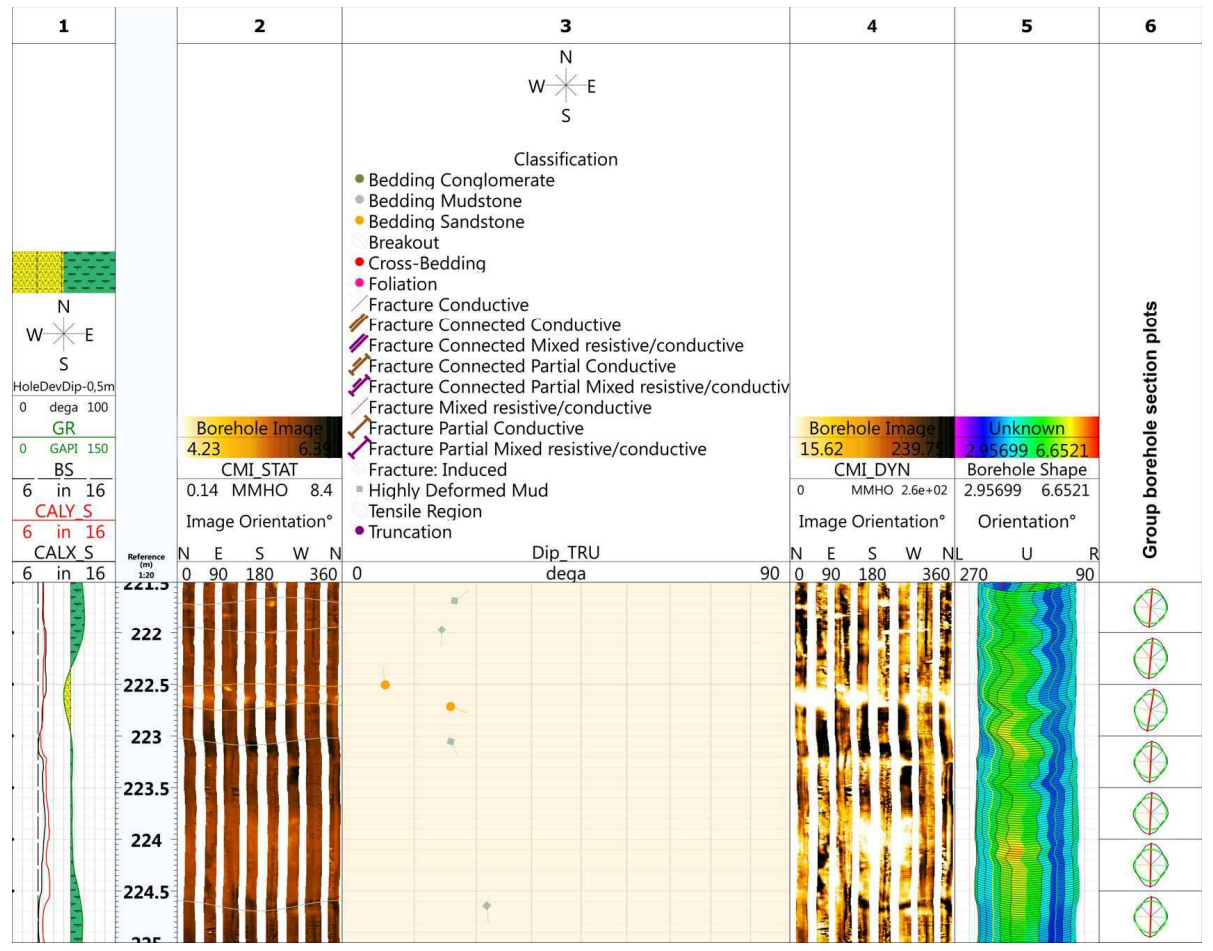

Fig. 7. Present-day in situ stress direction estimated from borehole breakouts identified on 8-arm caliper data recorded by the CMI tool, together with the electrical microconductivity data. Tracks: 1 auxiliary curves; 2 - CMI statically normalized image; 3 - dip / azimuth tadpoles plot; 4 - CMI dynamically normalized image; 5 - borehole wireframe model; 6 - "Potato Plot". 


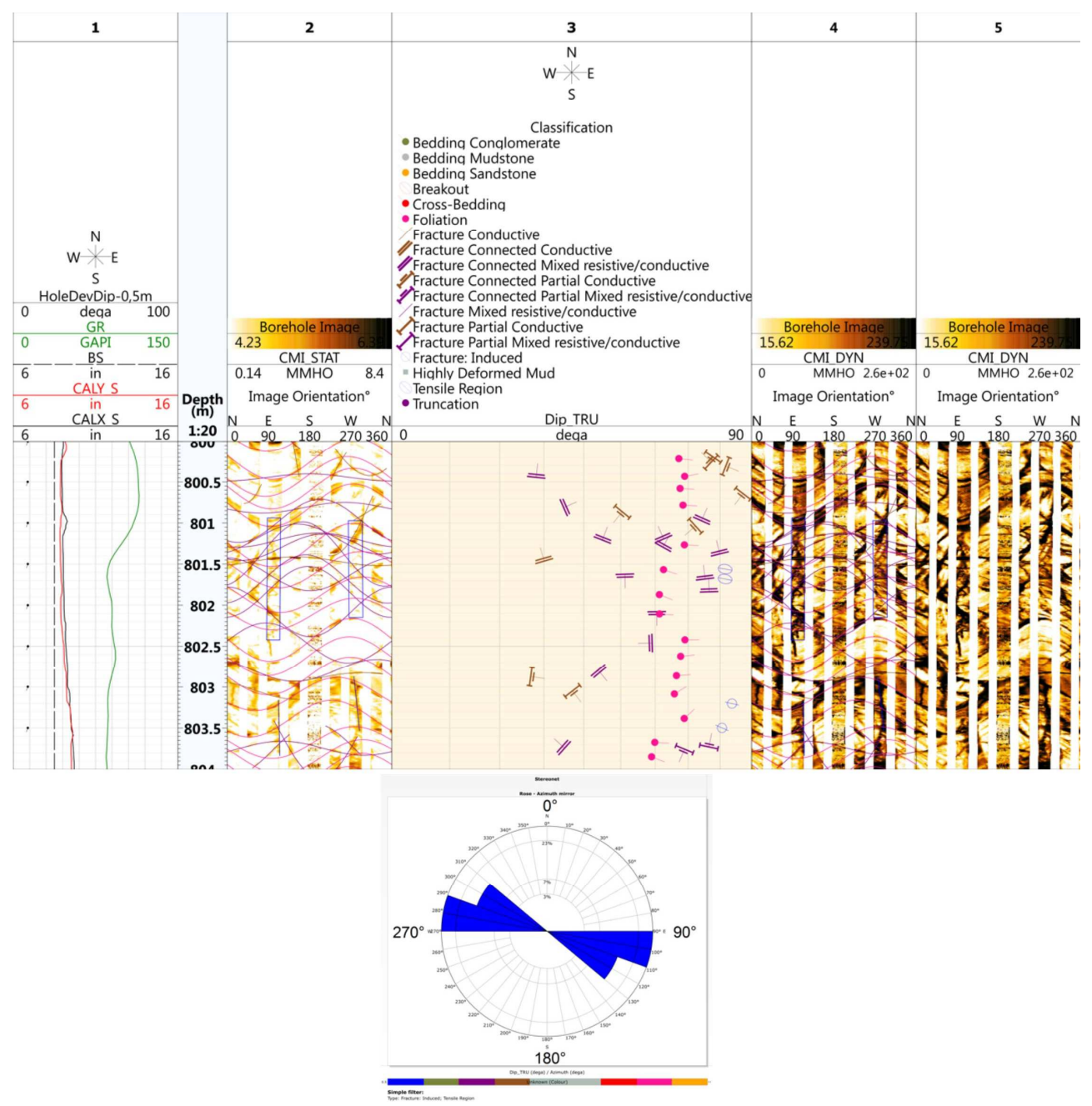

Fig. 8. Present-day in situ stress direction estimated from drilling-induced fractures and tensile zones. Tracks: 1 - auxiliary curves; 2 - CMI statically normalized image; 3 - dip / azimuth tadpoles plot; 4 and 5 - CMI dynamically normalized image. The azimuth frequency plot (Rose diagram) shows the predominant orientation of fractures.

\section{Conclusions}

Geophysical well logging investigation methods provide relevant and meaningful insights into the structure of the crystalline basement and its relationships with the sedimentary cover. We have analyzed and interpreted conventional and high-resolution (borehole electrical imaging) wireline logging data recorded in an exploration well drilled in North Dobrogean Promontory (Romania). This study demonstrates the applicability and the potential of these methods in order to identify and characterize the metamorphic foliations/schistosity and, possibly, metamorphic differentiations or mineralogical changes within the basement. Volumetric fracture intensity and formation brittleness characterization, as well as the identification of tectonic stress orientation via breakouts or drilling-induced fractures, are also illustrated in this research. 


\section{References}

1. R. Rickman, M.J. Mullen, J.E. Petre, W.V. Grieser, D. Kundert, A Practical Use of Shale Petrophysics for Stimulation Design Optimization: All Shale Plays Are Not Clones of the Barnett Shale, SPE Annual Technical Conference and Exhibition, paper SPE115258-MS, 840-850 (2008)

2. D. Gray, P. Anderson, J. Logel, F. Delbecq, D. Schmidt, R. Schmid, Estimation of stress and geomechanical properties using 3D seismic data, First Break 30, 3, 59-68 (2012)

3. W.S. Dershowitz, H.H. Herda, Interpretation of fracture spacing and intensity. In: J.R. Tillerson and W.R. Wawersik (eds.), Proceedings of the $33^{\text {rd }}$ U.S. Symposium on Rock Mechanics, A.A. Balkema, Rotterdam, 757-766 (1992)

4. Gavăt, I. Cornea, A. Gheorghe, R. Gaspar, L. Tomescu, La structure du soubassement moesien entre le Danube et les rivières du Ialomiţa, Buzău et Siret, Revue Roumaine de Géologie, Géophysique et Géographie, Serie Géophysique 11, 1, 23-32 (1967)

5. M. Săndulescu, Geotectonics of Romania (in Romanian), Technical Publishing House, Bucharest, 336 pp. (1984)

6. M. Tărăpoancă, Architecture, 3D geometry and tectonic evolution of the Carpathians foreland basin, Ph.D. Thesis, Vrije Universiteit, Amsterdam, ISBN 90-9017847-3 (2004)

7. I. Balintoni, C. Balica, Peri-Amazonian provenance of the Euxinic Craton components in Dobrogea and of the North Dobrogean Orogen components (Romania): A detrital zircon study, Precambrian Research 278, 34-51 (2016)

8. J.-C. Hippolyte, Geodynamics of Dobrogea (Romania): new constraints on the evolution of the Tornquist-Teisseyre Line, the Black Sea and the Carpathians, Tectonophysics 357, 33-53 (2002)

9. O. Mirăuță, E. Mirăuță, The Paleozoic from the southern part of the Măcin Mountains (Cerna-Hamcearca region) (in Romanian). Dări de Seamă ale Şedinţelor Comitetului Geologic (1958-1959), XLVI, 129-142 (1962)

10. O. Mirăuţă, Contributions to the knowledge of the Paleozoic Formations from the southern part of the Măcin Mountains (in Romanian). Studii şi Cercetări de Geologie, Geografie şi Geofizică, Seria Geol. 11, 2, 497-512 (1966)

11. D. Patrulius, E. Mirăuţă, M. Mureşan, M. Iordan, Stratigraphic and structural sinthesis of North Dobrogea. I. Paleozoic formations (in Romanian), Unpublished report, Archives of the Geological Institute of Romania, Bucharest (1973)

12. C.-C. Lee, C.-H. Lee, H.-F. Yeh, H.-I. Lin, Modeling spatial fracture intensity as a control on flow in fractured rock, Environmental Earth Sciences 63, 6, 1199-1211 (2010)

13. M.D. Zoback, D. Moos, L.G. Mastin, R.N. Anderson, Well bore breakouts and in situ stress, Journal of Geophysical Research 90 (B7), 5523-5530 (1985)

14. R.A. Plumb, S.H. Hickman, Stress-induced borehole elongation: A comparison between the Four-Arm Dipmeter and the Borehole Televiewer in the Auburn Geothermal Well, Journal of Geophysical Research 90 (B7), 5513-5521 (1985)

15. B.S. Aadnoy, Inversion technique to determine the in-situ stress field from fracturing data, Journal of Petroleum Science and Engineering 4, 127-141 (1990)

16. B.S. Aadnoy, J.S. Bell, Classification of drilling-induced fractures and their relationship to in-situ stress directions, The Log Analyst 39, 6, 27-42 (1998) 